Journal of Animal and Feed Sciences, 8, 1999, $611 \cdots 619$

\title{
The importance of washing the omasum for successful defaunation of sheep ${ }^{*}$
}

\author{
T. Michalowski ${ }^{1}$, J. Harmeyer ${ }^{2}$ and G. Bełżecki ${ }^{1}$ \\ 'The Kielanowski Institute of Animal Physiology and Nutrition, \\ Polish Academy of Sciences \\ 05-110 Jabtonna, Poland \\ 'Institute of Physiology, School of Veterinary Medicine \\ Bischofsholer Damm 15/102, 30173 Hannover, Germany
}

(Reccived 17 June 1999; accepted 7 October 1999)

\begin{abstract}
Four different methods for defaunating were tested. Small Entodinia but some times also other species of ciliates were found on the next day after defaunation when Aerosol OT was given in doses of 5 and $10 \mathrm{~g} / \mathrm{animal}$ or $1-1.5 \mathrm{~g} / \mathrm{kg}$ of rumen content. Emptying and washing the reticulorumen with a $0.9 \% \mathrm{NaCl}$ solution and subsequent freezing of the contents to $-20^{\circ} \mathrm{C}$ for $96 \mathrm{~h}$ resulted in absence of protozoa for a period of 10-14 days and this was followed by the re-establishment of a population of Eudiplodinium maggii, Entodinium simplex and Dasytricha ruminantium. Emptying and washing of the reticulo-rumen with warm $\left(40^{\circ} \mathrm{C}\right)$ water accompanied by heating of the contents to $70^{\circ} \mathrm{C}$ and addition of $10 \mathrm{~g}$ of Aerosol OT or $5 \mathrm{~g}$ sodium lauryl sulphate (SDS) climinated the ciliates from the rumen for a period of 7-40 days but re-establishment of small protozoa like Entodinium simplex and Entodinium caudatum was observed later.

Emptying the reticulo-rumen and washing the omasum, reticulum and rumen with warm water followed by heating of the contents to $70^{\circ} \mathrm{C}$ and the addition of Aerosol OT at a proportion of $1 \mathrm{~g} / \mathrm{kg}$ digesta resulted in elimination of all the species of ciliates from the reticulo-rumen of all defaunated sheep for a period longer than 70 days.
\end{abstract}

KEY WORDS: ciliates, defaunation, sheep, rumen, omasum

* Supported by State Committec for Scientific Research, Grant No 5P06E03615 and by the Alexander von Humboldt Foundation 


\section{INTRODUCTION}

The role of ciliates in the metabolism can be deduced from comparison of the same activities in faunated and defaunated ruminants. Different methods have been used to obtain ciliate-free ruminants. Becker et al. (1929) eliminated protozoa by administration of copper sulphate to the rumen. Dioctyl sodium sulphosuccinate (DSS; Aerosol OT) is the antiprotozoal agent used most often (Abou Akkada et al., 1968; Orpin, 1977; Lovelock et al., 1982; Kreuzer, 1986; Nagaraja et al., 1992). However, other surfactants such as nonyl phenol ethoxylate and sodium lauryl sulphate have also been used (Bird and Leng, 1978; Ashok et al., 1994). Linseed oil hydrolysate, $\mathrm{CaO}_{2}$ and lactic acid were also applied for defaunation of ruminants (Van Nevel and Demeyer, 1981; Demeyer, 1982; Mondeza et al., 1993). Jouany and Sénaud (1979) successfully defaunated sheep by evacuation of rumen contents, washing the reticulo-rumen walls with water and freezing the rumen content to kill the protozoa. To perform our experiments we tried to defaunate sheep by some of the methods mentioned above, but most of them were only partially successful. However we did obtain ciliate-free sheep when the rumen, reticulum and omasum were washed with water while the protozoa from the evacuated rumino-reticular digesta were killed by heating to $70^{\circ} \mathrm{C}$.

\section{MATERIAL AND METHODS}

Animals and feeds

Two Black Head and two Polish Merino adult sheep of body weight $60-76 \mathrm{~kg}$ and three growing Polish Merino lambs weighing 40-45 kg were used. The animals were provided with large rumen fistulas. They were housed in a separate building during each experimental session. Each sheep was kept in a separate pen with solid walls, without contact with others, and fed a hay-concentrate diet. The Black Head sheep were fed $150 \mathrm{~g}$ pelleted concentrate $(17 \% \mathrm{CP})$ at $8 \mathrm{a} . \mathrm{m}$. and 4 p.m. All Merino sheep received $130 \mathrm{~g}$ ground barley at 8 a.m. and 3 p.m. Hay and water were offered ad libitum.

\section{Defaunation procedures}

The following defaunation methods were tested:

Method A. The contents were withdrawn from the reticulo-rumen and kept for $96 \mathrm{~h}$ at $-20^{\circ} \mathrm{C}$ according to the method of Jouany and Sénaud (1979). The walls of the emptied forestomachs were washed many times with a warm $\left(40^{\circ} \mathrm{C}\right) \mathrm{NaCl}$ 
solution $(0.9 \% \mathrm{w} / \mathrm{v})$ instead of water and the rumen was filled thereafter with 81 of a buffer composed of $(\mathrm{g} / \mathrm{l}): \mathrm{NaCl}, 0.76 ; \mathrm{CH}_{3} \mathrm{COONa}, 6.12 ; \mathrm{H}_{2} \mathrm{HPO}_{4}, 3.48$; $\mathrm{NaH}_{2} \mathrm{PO}_{4}$ 1.38; $\mathrm{Na}_{2} \mathrm{HPO}_{4} \cdot 2 \mathrm{H}_{2} \mathrm{O}, 2.14 ; \mathrm{NaHCO}_{3} 2.1 ; \mathrm{MgCl}_{2} \cdot 6 \mathrm{H}_{2} \mathrm{O}, 0.3$; $\mathrm{CaCl}_{2} \cdot 2 \mathrm{H}_{2} \mathrm{O}, 0.22$ and supplemented with $14.7,15.0$ and $16.3 \mathrm{mmol}$ acetic, propionic and butyric acid, respectively. The buffer was exchanged every $12 \mathrm{~h}$. Finally, the rumen contents were thawed, heated to $40^{\circ} \mathrm{C}$ and added back to the rumen.

Method B. Aerosol OT (BDH, No. 560454R or Sigma No. D 4422) was given to the rumen of sheep in doses of 5 and $10 \mathrm{~g} /$ animal or $1-1.5 \mathrm{~g} / \mathrm{kg}$ rumen digesta. The weighed samples of detergents were dissolved in $200 \mathrm{ml}$ of water and either introduced to the rumen via the cannula or the digesta was withdrawn from the reticulo-rumen, mixed thoroughly with surfactant solution and returned to the rumen. The procedure was repeated on the next day.

Method $C$. Rumen contents were evacuated from the reticulo-rumen, heated to $70^{\circ} \mathrm{C}$ and allowed to stand at this temperature for $20-30 \mathrm{~min}$. The temperature of the digesta was then lowered to $40^{\circ} \mathrm{C}$ and a dose of $10 \mathrm{~g}$ of Aerosol OT or $5 \mathrm{~g}$ sodium lauryl sulphate (Ashok et al., 1994), dissolved in $500 \mathrm{ml}$ of water, was added to it and thoroughly mixed. The emptied reticulo-rumen was filled with warm $\left(40^{\circ} \mathrm{C}\right)$ water and the walls were carefully washed. The washing procedure was repeated 8 times and was followed by filling the rumen with 51 of a saline containing Aerosol OT at a concentration of $60 \mu \mathrm{g} / \mathrm{ml}$. The saline was removed after $3 \mathrm{~h}$ and the content was given back to the rumen. A new dose of the surfactant $(5 \mathrm{~g})$ was given on the next day and the complete defaunation procedure was repeated 7 days later.

Method $D$. The evacuation and heating the rumino-reticular digesta as well as the washing of the forestomach walls were the same as described above while about 101 of water was used for each washing. The additional step of this method was washing the omasum. This was performed by the use of a rubber hose, $10 \mathrm{~mm}$ in outer diameter, connected to a water-supply. The free end of the hose was fitted to a brass tube with a $9 \mathrm{~mm}$ outer diameter and about $8 \mathrm{~cm}$ in length. This metal tube was perforated with holes of about $2 \mathrm{~mm}$ diameter. The brass tube was inserted into the omasum and the contents were washed out with a stream of warm $\left(40^{\circ} \mathrm{C}\right)$ tap water. The procedure was repeated 4 times using about $1-21$ of for each wash. The majority of the water and omasal particulate matter flowed back into the reticulo-rumen via the reticulo-omasal orifice, which was kept open with the help of fingers, and was removed by suction. Finally, $1000 \mathrm{ml}$ of saline containing $100 \mathrm{mg}$ of Aerosol OT was infused into the omasum and this was followed by two washings of the reticulo-rumen. The rumino-reticular content was weighed and a solution of Aerosol OT was given in a proportion of $1 \mathrm{~g}$ surfactant $/ \mathrm{kg}$ digesta. The mixed digesta was then introduced into the rumen and the complete defaunation procedure was repeated on the next day. 
Examination of the rumen content for presence of ciliates

Samples of rumen contents were taken every two days before the morning feeding during the first two weeks and then two times a week. The fresh digesta was monitored microscopically for the presence of protozoa. Each sample of rumen content was examined three times; the volume of the monitored samples was $0.2-0.4 \mathrm{ml}$.

\section{RESULTS AND DISCUSSION}

Two Black Head sheep were defaunated by the modified method of Jouany and Sénaud (1979). Method $A$. The ruminal microfauna of the both animals, prior to defaunation, comprised Isotricha prostoma, Isotricha intestinalis, Dasytricha ruminantium, Eudiplodinium maggii, Anoplodinium denticulatum, Ostracodinium triloricatum and different species of entodinia of which the most numerous were Entodinium caudatum, Entodinium rostratum and Entodinium simplex. No protozoa were observed during the first 10-14 days following defaunating (Table 1). Eudiplodinium maggii re-established in both animals and achieved a concentra-

TABLE 1

Number of sheep defaunated by 4 different methods, number of defaunation attempts as well as length of the ciliate-free period after defaunation (days)

\begin{tabular}{cccc}
\hline $\begin{array}{l}\text { Defaunation } \\
\text { method }\end{array}$ & $\begin{array}{c}\text { Sheep } \\
\text { defaunated }\end{array}$ & $\begin{array}{c}\text { Number } \\
\text { of attempts }\end{array}$ & $\begin{array}{c}\text { Length of } \\
\text { ciliate-free period }\end{array}$ \\
\hline A $^{*}$ & 2 & 4 & $10-14$ \\
B & 5 & 8 & $0-20$ \\
C & 5 & 10 & $7-40$ \\
D & 4 & 4 & $>70$ \\
\hline
\end{tabular}

* - see Material and Methods

tion of 45-61 $\times 10^{3}$ cells/g rumen content as early as three weeks after defaunation. Eudiplodinium maggii was the only species in the rumen of one sheep but was accompanied by Dasytricha ruminantium and Entodinium simplex in the second. The highest concentration of this last species was $3 \times 10^{5} / \mathrm{g}$ while the population density of Dasytricha ruminantium did not exceed $2 \times 10^{3}$ cells per gram of rumen content. Repeated defaunation resulted in a similar length of the period when no protozoa were observed. Thus, the obtained results showed that the method mentioned above was only partially successful, and are in good accordance with the results of Lovelock et al. (1982). 
All five Polish Merino sheep were defaunated with different doses of Aerosol OT (Method B). The rumen microfauna of the adult sheep prior to defaunation consisted of Isotricha prostoma, Isotricha intestinalis, Dasytricha ruminantium, Eudiplodinium maggii, Epidinium ecaudatum and numerous species of the genus Entodinium. Neither 5 nor $10 \mathrm{~g}$ of Aerosol OT given to the rumen of both adult animals on two consecutive days eliminated the ciliates from the rumen and practically all of the ciliate species were present on the next day following treatment. A single dose of $28 \mathrm{~g}$ of Aerosol OT, i.e. about $1.5 \mathrm{~g} / \mathrm{kg}$ rumen digesta, was also ineffective when it was given to the rumen of one adult Merino sheep. Starvation of the second adult sheep for $24 \mathrm{~h}$ before treatment with the same detergent affected the length of the ciliatc-free period but small Entodinia were found as soon as on the 7 th day after treatment and this was followed by the spontaneous re-establishment of other species. Our findings contradict the results of other authors who were able to eliminate the protozoa from the rumen by the use of dioctyl sodium sulphoscuccinate (Orpin, 1977; Lovelock et al., 1982; Nogia and Rita, 1994). The differences in feeding regimes could explain this discrepancy. All our sheep were fed ad libitum with hay. Due to this the rumen of all of the sheep were completely filled with feed. Such conditions could preclude good mixing of the digesta, resulting in the concentration of surfactant being too low in some portions of the rumen to destroy the protozoa. According to Orpin (1977) a concentration of Aerosol OT of $1000-2000 \mu \mathrm{g} / \mathrm{ml}$ is necessary to remove ciliates from the rumen.

All of the five Merino sheep were defaunated by evacuation and heating of the rumen content accompanied by washing of the reticulo-rumen walls and mixing different doses of Aerosol OT or sodium lauryl sulphate with the digesta, i.e $5 \mathrm{~g} /$ animal (both adult sheep) or $10 \mathrm{~g} / \mathrm{sheep} \mathrm{(three} \mathrm{growing} \mathrm{animals)} \mathrm{(Method}$ $C$ ). The ciliate fauna before defaunation consisted of large ophryoscolecids Eudiplodinium maggii and Epidinium ecaudatum and numerous species of the genus Entodinium (Figure 1A) as well as ruminal holotrichs i.e. Isotricha intestinalis, Isotricha prostoma and Dasytricha ruminantium. No ciliates were observed for a period of 10-40 days after defaunation (Table 1) and this ciliate-free period was followed by re-establishment of Entodinium caudatum and Entodinium simplex. The concentration of these ciliates increased during 2 weeks to over $10^{5} / \mathrm{g}$. Thus the procedure was repeated in the case of both adult sheep, but Entodinia re-established in both cases. All three growing sheep with the re-established population of both species of Entodinium were defaunated with Aerosol OT. The contents were withdrawn from the rumen, thoroughly mixed with detergent solution ( $1 \mathrm{~g}$ Aerosol OT/kg digesta), and introduced back as soon as possible. The complete defaunation procedure was repeated on the next day. The protozoa were found again not later than 20 days after defaunation. This shows that both methods were only partially successful. It is possible that not all of the ciliates 
were removed from the reticulo-rumen or they passed back to the rumen from the omasum (Towne and Nagaraja, 1990).

Three growing Merino sheep with re-established populations of Entodinium (see above) and one of the adult Merinos with a mixed population of ciliate protozoa (Figure 1A) that developed as a result of reinfection, were defaunated by evacuation and heating of the reticulo-rumen contents accompanied by washing of the reticulo-rumen and omasum (Method $D$ ). Aerosol OT was added to the digesta at a ratio of $1 \mathrm{~g} / \mathrm{kg}$ digesta. No protozoa were observed for a period exceeding 70 days (Table 1, Figure 1B). The adult sheep was then reinoculated with Eudiplodinium maggii from in vitro cultures. About $150 \times 10^{3}$ protozoans were given to the rumen, resulting in the development of a population of these ciliates over a 2-week period (Figure 1C). Eudiplodinium maggii was the only ciliate species present in the rumen for the next 2 months while the three growing sheep were still ciliatefree. This suggests that omasum washing was the important step in preparation of the ciliate-free rumen. Flushing the omasal canal with tap water without, however, removing digesta embedded between the omasal laminae was performed by Towne and Nagaraja (1990). In our method the omasum was washed four times in two consecutive days and the stream of water was directed not only into the omasal canal but also between the leaves. This was done by inserting the perforated brass tube into the omasum and using this device to also clean the interlamellar space. The omasum must have been effectively emptied, since it was not possible to locate the organ by palpation from inside the rumen, whereas this was easily achievable before the washing when it presented as a relatively solid organ, expanding into the right rumen wall.

Towne and Nagaraja (1990) feared that repeated flushing of the omasum would lead to water intoxication of animals. This was, however, not observed here and all four sheep bchaved normally and started to eat hay directly after the defaunation procedure finished as well as on the following days. We did observe that the sheep excreted more urine over the first night after defaunation. They perhaps eliminated in this way an excess of the washing water that passed down from the omasum to the duodenum and small intestine.

The sheep were housed in a separate building during the defaunating sessions and kept individually in separate pens with solid walls. Due to this contamination of the defaunated animals by microorganisms from other sheep was rather improbable. We think that the reappearance of ciliates in the rumen was due to incomplete defaunation. It appears somewhat surprising that up to 40 days can pass in case of incomplete defaunation before some protozoal species that survived defaunation had recovered and reconstituted a new population. We think that the generation time of protozoal cells could be much longer than $24 \mathrm{~h}$ during the first few days after defaunation since ciliates may have been metabolically damaged by the harsh conditions associated with defaunation. Some cells of ciliates may possibly 
$1 \mathrm{~A}$

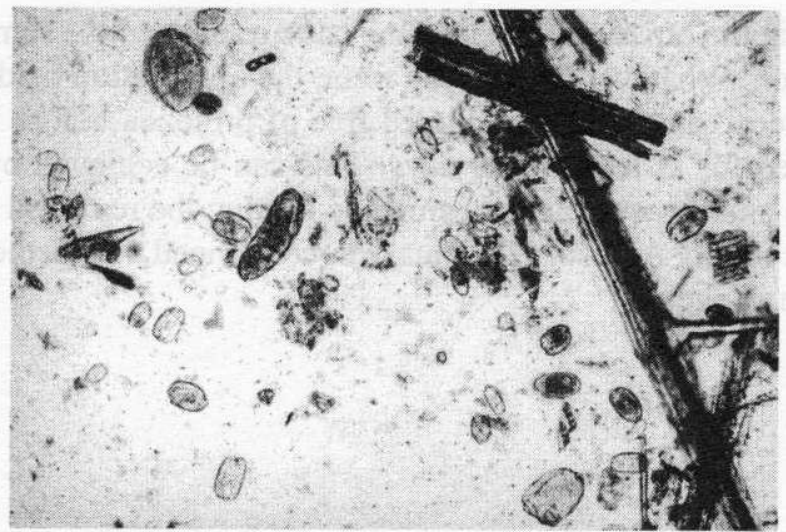

$1 \mathrm{~B}$
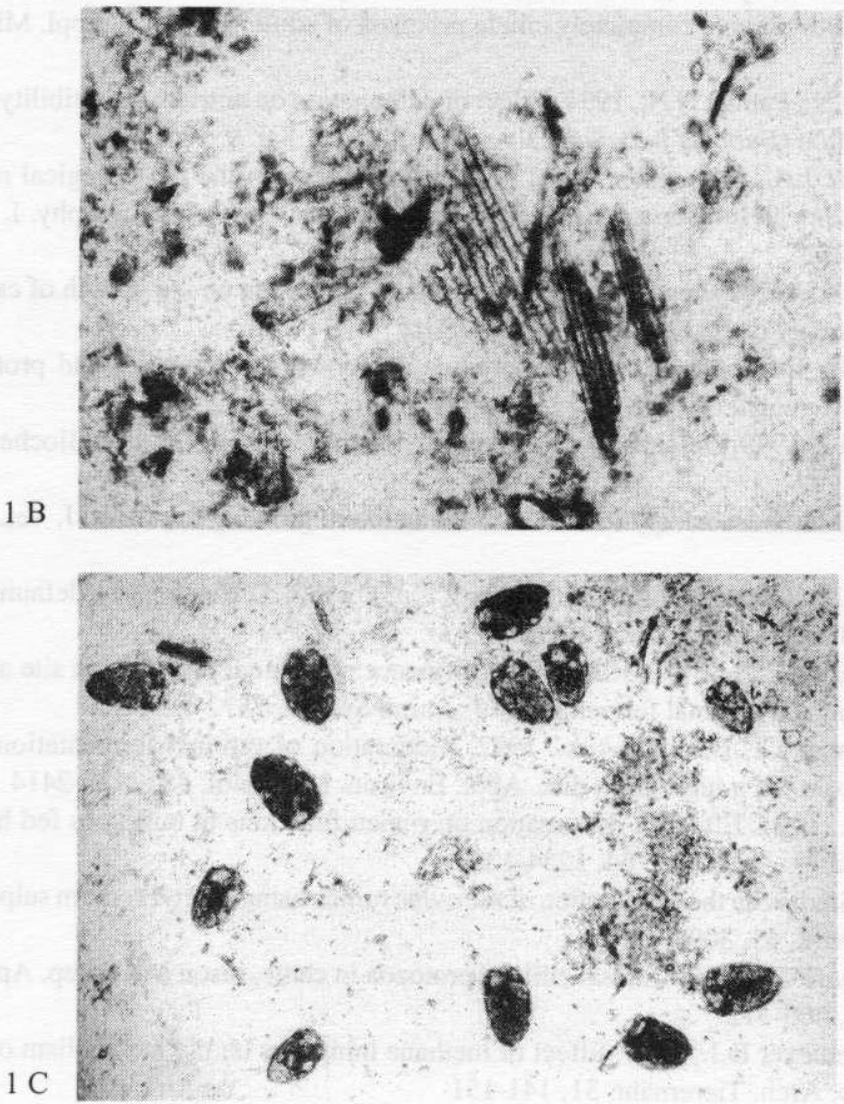

Figure 1. Photomicrographs of the rumen fluid of the one of adult Polish Merino sheep before defaunation (A), on $70^{\text {th }}$ day after defaunation by the washing of the reticulo-rumen and omasum (B) and on 14th day after reinoculation with Eudiplodinium maggii from the in vitro cultures (C) 
have survived in the omasum but they may have re-entered the rumen many days after defaunation. Whatever the reasons were, the observation made in this study show that a sheep can not be considered free of protozoa before this status has been maintained for at least 30-40 days. This can be achieved by washing the reticulo-rumen and omasum accompanied be heating the removed rumen digesta up to $70^{\circ} \mathrm{C}$ and adding Aerosol OT. Thus, we recommend this method for successful defaunation of sheep.

\section{REFERENCES}

Abou Akkada A.R., Bartley E.E., Berube R., Fina L.R., Meyer R.M., Hendricks D., Julius F., 1968. Simple method to remove completely ciliate protozoa of adult ruminants. Appl. Microbiol. 16, 1475-1477

Ashok S., Kamra D.N., Pathak N.N., 1994. Effect of defaunation on nutrient digestibility and growth of Murrah buffalo (Bubalus bubalus) calves. Int. J. Anim. Sci. 9. 185-187

Becker E.R., Schulz J.A., Emmerson M.A., 1929. Experiments on the physiological relationships between the stomach infusoria of ruminants and their hosts, with bibliography. I. Statc. Coll. J. Sci, 4, 215-25!

Bird S.H., Leng R.A., 1978. The effects of defaunation of the rumen on the growth of catte on lowprotein high-energy diets. Brit. J. Nutr. 40, 163-167

Demeyer D.I., 1982. Influence of calcium peroxide on fermentation pattern and protozoa in the rumen. Arch. Tierenähr. 32, 7-8

Jouany J.P., Sénaud J., 1979. Defaunation du rumen de mouton. Ann. Biol. Anim. Biochem. Biophys. $19,619-624$

Kreuzcr M., 1986. Methods and application of defaunation in growing ruminant. J. Vet. Med. A 33, $721-745$

Lovelock L.K.A., Buchanan-Smith J.G., Forsberg C.W., 1982. Difficulties in defaunation of the ovine rumen. Can. J. Anim. Sci. 62, 299-303

Mondeza G.D., Britton R.A., Stock R.A., 1993. Influence of ruminal protozoa on site and extent of starch digestion and ruminal fermentation. J. Anim. Sci. 71, 1572-1578

Nagaraja T.G., Towne G., Beharka A.A., 1992. Moderation of ruminal fermentation by ciliated protozoa in cattle fed a high-grain dict. Appl. Environ. Microbiol. 58, 2410-2414

Nogia O.P., Rita S., 1994. Effect of defaunation on rumen functions in buffaloes fed high concentrate diet. Indian J. Anim. Sci. 64, 1254-1258

Orpin C.G., 1977. Studies on the defaunation of the ovine rumen using dioctyl sodium sulphosuccinate. J. Appl. Bacteriol. 43, 309-318

Towne G., Nagaraja T.G., 1990. Omasal ciliated protozoa in cattlc, bison and sheep. Appl. Environ. Microbiol. 56, 409-412

Van Nevel C.J., Demeyer D.I., 1981. Effect of methane inhibitors on the metabolism of rumen microbes in vitro. Arch. Tierernähr. 31, 141-151 


\section{STRESZCZENIE}

\section{Znaczenie wyplukiwania ksiąg w skutecznej defaunacji owiec}

Badano skuteczność czterech metod defaunacji żwacza owiec, spośród których trzy są znane z piśmiennictwa. Czwarta metoda została zastosowana po raz pierwszy. Stwierdzono, że powszechnie stosowany detergent, Aerozol OT, był nieskuteczny w dawkach 5 oraz $10 \mathrm{~g} /$ zwierzę lub $1-1,5 \mathrm{~g} / \mathrm{kg}$ treści żwacza, żywe orzęski stwierdzono bowiem już następnego dnia po podaniu preparatu. Opróżnienie czepco-żwacza i dokładne wymycie nabłonka wyścielającego narząd oraz zamrożenie treści do $-20^{\circ} \mathrm{C}$ przez 96 godzin eliminowało pierwotniaki na okres 10-14 dni. Po tym czasie pojawiły się w żwaczu orzęski z gatunku Eudiplodinium maggii, Entodinium simplex i Dasytricha ruminantium. Opróżnienie czepco-żwacza i wielokrotne przemycie wyścielającego nabłonka ciepłą wodą w połączeniu z podgrzaniem treści żwacza do $70^{\circ} \mathrm{C}$ i dodaniem 5 lub $10 \mathrm{~g}$ detergentu (Aerozol OT lub SDS) usuwało pierwotniaki ze żwacza na 7 do 40 dni. Po tym okresie pojawiały się małe pierwotniaki, takie jak Entodinium simplex i Entodinium caudatum. Własna metoda, w której oprócz opróżnienia czepco-żwacza i wymycia ścian, podgrzaniu wyjętej treści do $70^{\circ} \mathrm{C}$ i dodaniu detergentu (Aerozol OT) w ilości $1 \mathrm{~g} / \mathrm{kg}$ treści, wypłukano czterokrotnie księgi, usuwając całą ich treść, pozbawiła owce pierwotniaków na dłużej niż 70 dni. 